\section{American lobsters (Homarus americanus) not surviving during air transport: evaluation of microbial spoilage}

\author{
Erica Tirloni, Simone Stella, \\ Mario Gennari, Fabio Colombo, \\ Cristian Bernardi
}

Department of Health, Animal Science and Food Safety, University of Milan, Milan, Italy

\section{Abstract}

Eighteen American lobsters (Homarus americanus), dead during air transport, were analysed in order to evaluate the microbial population of meat, gills and gut: no specific studies have ever been conducted so far on the microbiological quality of American lobsters' meats in terms of spoilage microbiota. The meat samples showed very limited total viable counts, in almost all the cases below the level of $6 \mathrm{Log} \mathrm{CFU} / \mathrm{g}$, while higher loads were found, as expected, in gut and gills, the most probable source of contamination. These data could justify the possibility to commercialise these notsurviving subjects, without quality concerns for the consumers. Most of the isolates resulted to be clustered with type strains of Pseudoalteromonas spp. (43.1\%) and Photobacterium spp. (24.1\%), and in particular to species related to the natural marine environment. The distribution of the genera showed a marked inhomogeneity among the samples. The majority of the isolates identified resulted to possess proteolytic (69.3\%) and lipolytic ability (75.5\%), suggesting their potential spoilage ability. The maintanance of good hygienical practices, especially during the production of ready-to-eat lobsters-based products, and a proper storage could limit the possible replication of these microorganisms.

\section{Introduction}

The $90 \%$ of fish international market is based on processed products, but live crustaceans, especially clawed and spiny lobsters, crabs, marine and freshwater prawns and freshwater crayfish, are really appreciated for their high nutritional and commercial importance (Fotedar and Evans, 2011). The American lobster, Homarus americanus, is one of the most important commercial species marketed internationally and one of the major economic resource of the coastal communities of North America, with more than 130,000 tons of alive animals commercialised worldwide in 2006 and producing nearly 545 million of euros of profits. Due to the decrease of the European lobster Homarus gammarus catching figures, American lobsters are imported by several European countries, especially Mediterranean ones: in Italy about 4387 tons are annually introduced for an economic value of 44 million of euros (Barrento et al., 2009; FAO, 2006). American lobsters are mainly commercialised alive and cooked before consumption. After the capture and during the air transport, they are submitted to several stresses like air exposure, changes of the natural environments in terms of physical and chemical parameters such as water salinity and temperature, hypoxia, fasting, interactions with other conspecifics and human handling. These stressors can affect their health, reducing their quality, and in some cases could be lethal. Opposite opinions are still existing about the edibility of lobsters dead during air shipping: some sellers reject to sale the dead subjects, some others use these ones for cooked products, others sell these animals depreciated. At the moment there are no available studies about the hygienic quality of the living and dead animals, in terms of presence of potential pathogenic bacteria and of microbial populations. However, we could suppose that the loads and the typology of microbiota of lobsters reflect a combination of factors including the environment where they are captured, their feeding and living practices, the season of capture as well as the quality and temperature of the waters where they lived, as already demonstrated for other crustaceans and for finfish (Liston, 1980; Shewan, 1977). After death, once the immune response fails to function and the muscular structure declines due to microbial activity, the alteration begins quickly: generally this situation does not expose consumer to microbiological risks as these animals are mainly consumed after cooking. However, the increasing demand for ready-to-eat raw or cooked crustaceans and of fresh lobster tails could enhance the risk posed by these products, if subjected to improper storage or poor hygienic practices during production and commercialisation. Swartzentruber et al. (1980) found high total bacterial count values [more than 5 Log colony forming unit (CFU)/g] in 51.9\% of frozen lobster tails samples, even if very low levels of coliforms and $E$. coli were detected. Although, as already mentioned, no studies till now were conducted on lobster meat bacterial population, generally the microbiota of crustaceans captured in temperate waters includes Pseudomonas spp., Shewanella putrefaciens and members of the group AcinetobacterPsychrobacter (Gram and Huss, 1996).

Aim of our study was the microbial evalua-
Correspondence: Cristian Bernardi, Department of Health, Animal Science and Food Safety, University of Milan, via G. Celoria 10, 20133 Milan, Italy.

Tel: +39.02 .50317855 - Fax: +39.02 .50317870 .

E-mail: cristian.bernardi@unimi.it

Acknowledgements: the authors would like to thank METRO Italia SpA for providing the American lobsters. Professor Patrizia Cattaneo should also be acknowledged for her careful revision of the manuscript.

Key words: Dead American lobsters; Shipping; Food spoilage; Microbial population.

Contributions: ET and SS were involved in microbiological analyses and writing of the paper. FC was involved in biomolecular analyses. MG was involved in phenotypical tests. CB was involved in biomolecular analyses, reference search and planning of the trial.

Funding: the study was funded by the University of Milan, Piano di Sostegno alla Ricerca 2014, Linea $B$.

Conflict of interest: the authors declare no poten tial conflict of interest.

Received for publication: 3 November 2015.

Revision received: 25 January 2016.

Accepted for publication: 26 January 2016 .

This work is licensed under a Creative Commons Attribution-NonCommercial 4.0 International License (CC BY-NC 4.0).

(C) Copyright E. Tirloni et al., 2016

Licensee PAGEPress, Italy

Italian Journal of Food Safety 2016; 5:5620

doi:10.4081/ijfs.2016.5620

tion of the meat of American lobsters not surviving the air shipping from the harvest (USA) to a seafood distribution platform of an international wholesaler, located in Northern Italy, and the identification of the most representative bacterial populations in order to establish the major genera/species involved with microbial spoilage of these products. We also evaluated the microbial loads of gut and gills as possible sources of contamination.

\section{Materials and Methods}

\section{Microbiological analyses}

For this study, eighteen lobsters arrived dead after air transport lasted about $24 \mathrm{~h}$ from harvest (USA) to the seafood distribution platform, were collected. The subjects were transported at refrigeration temperatures in cardboard boxes containing ice gel packs where they were maintained separately thanks to 
cardboard dividers. The dead subjects were transported under refrigerated conditions to the laboratory where they were analysed immediately. Aseptically, gills, meat and intestine were withdrawn and submitted to microbiological analyses: 5-10 g of each sample were diluted $1: 10$ in saline diluent $(\mathrm{NaCl} 10 \mathrm{~g} / \mathrm{L}$, $\mathrm{MgSO}_{4} \cdot 7 \mathrm{H}_{2} \mathrm{O} 1.53 \mathrm{~g} / \mathrm{L}, \mathrm{MgCl}_{2} \cdot 6 \mathrm{H}_{2} \mathrm{O} 1.28 \mathrm{~g} / \mathrm{L}, \mathrm{KCl}$ $0.19 \mathrm{~g} / \mathrm{L}$, tryptone $1 \mathrm{~g} / \mathrm{L}$ ) and serial 10 -fold dilutions were prepared. Total viable count (TVC) was enumerated onto modified Tryptose agar as described by Bernardi et al. (2015), incubated at $20^{\circ} \mathrm{C}$ for $72 \mathrm{~h}$. The number of Enterobacteriaceae was determined according with IS0 21528-2:2004 method (ISO, 2004). Colonies of fluorescent pseudomonads were observed on plates of King's B agar (King et al., 1954) in ultraviolet light, after growth for 1-3 days at $20^{\circ} \mathrm{C}$. Bioluminescent bacteria were enumerated onto glycerol based marine agar (GMA) (Makemson et al., 1992); plates were incubated at $20^{\circ} \mathrm{C}$ for $72 \mathrm{~h}$ and observed daily in dark. Finally $\mathrm{H}_{2} \mathrm{~S}$ producing microorganisms were enumerated onto Iron Agar containing sodium thiosulphate (IA1 following Gram et al., 1987) using the pour plate technique. Plates were incubated at $20^{\circ} \mathrm{C}$ for $72 \mathrm{~h}$ and observed for black colonies.

\section{Phenotypical tests}

From the TVC plates of meat samples, a number of five colonies for each of 12 subjects (identified with code from A to $\mathrm{N}$ ) were randomly picked and subcultured onto modified Tryptose agar. The total of 60 isolates were afterwards submitted to the tests as described below.

The following reactions and biochemical tests were used for the characterisation of the isolates. Gram-reaction was tested by the $\mathrm{KOH}$ method (Gregersen, 1978). Phase contrast microscopy was used for the determination of shape and motility. Cytochrome-oxidase was tested with the method described by Kovacs (1956) and catalase formation with $3 \% \mathrm{H}_{2} \mathrm{O}_{2}$.

The carbohydrate metabolism was observed in tubes of Hugh and Leifson medium (Hugh and Leifson, 1953). Tubes were stab inoculated (after boiling to avoid oxygen) and incubated at $20^{\circ} \mathrm{C}$ for a week. Fermentative bacteria produced acid from glucose, changing the color of the indicator from green to yellow, in all the volume of the medium. Oxidative bacteria grew only on the surface of the medium, and the eventual change of color (blue due to alcalinisation or yellow for acidification) was located within 2-3 cm from the surface.

Proteolytic activity was detected by gelatin hydrolysis on Frazier's agar plates (Frazier, 1926). The inoculated plates were incubated at $20^{\circ} \mathrm{C}$ for a week, than flooded with Frazier's reactive. Gelatinase activity was indicated by formation of a clear zone around the positive colonies.
Lipolytic activity was assessed on Sierra's agar containing Tween 80 (Sierra, 1957). The plates were incubated at $20^{\circ} \mathrm{C}$ for a week; positive strains showed a visible precipitation around the colonies.

All the isolates were screened for their ability to produce $\mathrm{H}_{2} \mathrm{~S}$. The medium used was Iron agar 1 (Gram et al., 1987); each plate was prepared with $40 \mathrm{~mL}$ of agar stab inoculated. $\mathrm{H}_{2} \mathrm{~S}$ production was indicated by the formation of a black precipitate of FeS. To enable the growth of halophilic microorganisms, the original composition of some media (Iron Agar 1) were added of the following final salt concentrations: $\mathrm{NaCl} 10 \mathrm{~g} / \mathrm{L}, \mathrm{MgSO}_{4} \cdot 7 \mathrm{H}_{2} \mathrm{O} 1.53 \mathrm{~g} / \mathrm{L}$, $\mathrm{MgCl}_{2} \cdot 6 \mathrm{H}_{2} \mathrm{O} 1.28 \mathrm{~g} / \mathrm{L}, \mathrm{KCl} 0.19 \mathrm{~g} / \mathrm{L}$.

The ability to growth at $5,30,37$ and $42^{\circ} \mathrm{C}$ was tested isolating each of the strain onto plates of modified Tryptose agar. Moreover the ability to grow onto modified tryptose agar including different salt concentration ( 0 and $0.5 \%$ ) was evaluated preparing the plates with the different percentages of salt included.

\section{Sequencing of $16 \mathrm{~s}$ rRNA gene}

Isolates were then identified by $16 \mathrm{~s} r R N A$ gene sequencing (Eurofins, Berlin, Germany) using the standard forward primers CC-CD as described by Rudi et al. (1997). The sequences were analysed and compared to BIBI and NCBI-Blast (http://blast.ncbi.nlm.nih. gov/Blast.cgi) databases and the closest type strains relatives based on partial $16 \mathrm{~S}$ rRNA gene sequences were determined. In order to verify if the number of identified taxa was representative of the whole microbial species present in the ecological niche of American lobsters meat, the total number of bacterial species and the percentage detected were estimated by method described by Chao et al. (2009) for incidence data.

Table 1. Mean bacterial counts, number of countable samples and number of samples under the 6 Log limit of meat, gills and gut of American lobsters.

\begin{tabular}{|c|c|c|c|}
\hline & & $\begin{array}{c}\text { Mean } \pm \text { SD } \\
\text { (no. of countable } \\
\text { samples) }\end{array}$ & $\begin{array}{c}\text { Detection limit of } 6 \text { Log level } \\
\text { (no. of samples } \\
\text { under the limit) }\end{array}$ \\
\hline $\operatorname{TVC} 20^{\circ} \mathrm{C}$ & $\begin{array}{c}\text { Meat } \\
\text { Gills } \\
\text { Gut }\end{array}$ & $\begin{array}{l}4.5 \pm 0.9(n=16) \\
7.1 \pm 0.8(n=12) \\
6.5 \pm 1.3(n=16)\end{array}$ & $\begin{array}{l}<2(\mathrm{n}=2) \\
<2(\mathrm{n}=0) \\
<2(\mathrm{n}=0)\end{array}$ \\
\hline Bioluminescent bacteria & $\begin{array}{l}\text { Meat } \\
\text { Gills } \\
\text { Gut }\end{array}$ & $\begin{array}{c}3.1 \pm 0.9(n=7) \\
4.4 \pm 1.6(n=10) \\
4.3 \pm 1.5(n=8)\end{array}$ & $\begin{array}{l}<2(n=8) \\
<2(n=2) \\
<2(n=5)\end{array}$ \\
\hline $\mathrm{H}_{2} \mathrm{~S}$ producing bacteria & $\begin{array}{l}\text { Meat } \\
\text { Gills } \\
\text { Gut }\end{array}$ & $\begin{array}{l}2.4 \pm 1.4(n=6) \\
4.0 \pm 1.4(n=7) \\
3.3 \pm 1.4(n=8)\end{array}$ & $\begin{array}{l}<1(\mathrm{n}=9) \\
<1(\mathrm{n}=3) \\
<1(\mathrm{n}=5)\end{array}$ \\
\hline Enterobacteriaceae & $\begin{array}{l}\text { Meat } \\
\text { Gills } \\
\text { Gut }\end{array}$ & $\begin{array}{c}(n=0) \\
3.6 \pm 1.3(n=3) \\
3.7 \pm 2.0(n=3)\end{array}$ & $\begin{array}{l}<2(\mathrm{n}=15) \\
<2(\mathrm{n}=9) \\
<2(\mathrm{n}=10)\end{array}$ \\
\hline
\end{tabular}

SD, standard deviation; TVC, total viable count.

\section{Results and Discussion}

A total of 18 lobsters dead during shipping were analysed: meat, gills (as the main access point for bacteria) and gut bacterial contaminations were screened. The Food and Drug Administration (FDA, 2013), which has issued guidelines in order to define the microbiological quality of some food categories, indicates in $6 \mathrm{Log} \mathrm{CFU} / \mathrm{g}$ the microbiological limit for crustaceans raw meat. There are no specific studies about the microbiological quality of American lobsters' meat; studies are available on frozen crabs meat (ICMSF, 1998), indicating that counts below 5 Log CFU/g can be considered satisfactory, while those comprised between 5 and 6 Log CFU/g should be considered fairly satisfactory. Moreover, for fish products, the threshold value used to identify the end of the shelf-life is often $6 \mathrm{Log} \mathrm{CFU} / \mathrm{g}$ (Olafsdottir et al., 2005), even if the total bacterial count at the point of rejection can be around 7-8 Log CFU/g (Espe et al., 2004). Generally, the values obtained from our raw meat samples were characterised by limited loads: the average was below $5 \mathrm{Log}$ CFU/g, confirming a good hygienic quality, while only two samples resulted to exceed the 6 Log level (6.21 and 6.38 Log CFU/g) (Table 1). As expected, gills and guts were characterised by higher loads: in the intestine this is due to the presence of a great amount of bacteria which constitute the natural microbiota, while the gills were identified as the main point of access of the bacteria from the outside due to the peculiar anatomical structure that allows gaseous exchanges. These loads, in any case, do not represent a hygienic problem as the product is generally consumed after a thermal treatment. However, in order to avoid the cross contami- 
nation between raw products during the preparation, the good manufacturing and hygienic practices should be always applied. Concerning the other parameters evaluated, all the counts of meat samples resulted low (average values of bioluminescent and $\mathrm{H}_{2} \mathrm{~S}$ producing bacteria were always below 4 Log CFU/g). Considering $\mathrm{H}_{2} \mathrm{~S}$ producing bacteria, typical spoiler of fish products, although the loads detected in meat samples do not reach high levels, they should be carefully considered, due to their potential replication during the incidental further storage at low temperatures. For all the parameters, higher values were detected in gills and gut. Considering Enterobacteriaceae and fluorescent pseudomonads, all the samples were below the detection limit ( $2 \mathrm{Log}$ CFU/g). The absence of detectable counts of fluorescent pseudomonads was unexpected, as these microorganisms are common contaminants of marine fishes (Huss, 1995).

In order to understand the ecology of the strains grown on the plates of the total viable count of meat samples, some phenotypic traits were considered: the $43.1 \%$ resulted to ferment glucose while the remaining $56.9 \%$ to be oxidative. Considering the ability to grow at different temperatures, the psychrotrophic nature of the microbiota was evidenced, even if the ability to adapt to higher temperatures was also observed. In fact, all the isolates grew at refrigerated temperatures $\left(5^{\circ} \mathrm{C}\right)$, the $46.6 \%$ of the isolates was able to grow at $30^{\circ} \mathrm{C}$ while only the $3.4 \%$ resulted to be able to grow at $37^{\circ} \mathrm{C}$ and none of the isolates was able to grow at $42^{\circ} \mathrm{C}$. Taking in account the salt requirement, the $82.8 \%$ of isolates resulted to be able to grow at $0.5 \%$ of salinity, while only the $24.1 \%$ at $0 \%$, evidencing that the main lobster bacterial population is composed by halotolerant and halophilic microorganisms. From the 60 isolates randomly picked from the plates of meat samples, 2 were lost due to their short surviving in vitro. All the isolates were Gram Negative (Table 2).

The isolates clustered mostly (43.1\%) with type strains from Pseudoalteromonas spp.: this is one of the largest genera within the Gammaproteobacteria and currently comprises more than 30 species (Ivanova et al., 2004). These microorganisms are characterised by a widespread distribution across many marine habitats (e.g., seawater, rocks, macroalgae and marine animals) and are able to survive in poor nutrient substrates producing a varied range of metabolites and enzymes (Ivanova $e t$ al., 2003). The phylogenetic structure of this group indicates that the non-pigmented species are strictly related among them and constitute the major cluster of the genus. In our case, 25 isolates were identified as Pseudoalteromonas spp.: 20 isolates (80\%) resulted to be closely related to the species $P S$.
Table 2. Biomolecular identification of bacterial isolates from American lobsters meat and similarity rate.

\begin{tabular}{|c|c|c|}
\hline Subject code & Isolate number & Closest relative in database and similarity rate \\
\hline A & 1 & Pseudoalteromonas paragorgicolalelyakovi/distincta/nigrifaciens (99\%) \\
\hline A & 2 & Pseudoalteromonas paragorgicolalelyakovi/distincta/nigrifaciens (99\%) \\
\hline A & 3 & Psychrobacter submarinus (99\%) \\
\hline A & 4 & Pseudoalteromonas paragorgicolalelyakovi/distincta/nigrifaciens (99\%) \\
\hline A & 5 & Pseudoalteromonas paragorgicolalelyakovi/distincta/nigrifaciens (99\%) \\
\hline B & 6 & Photobacterium kishitani/piscicola (99\%) \\
\hline B & 7 & Photobacterium kishitani (99\%) \\
\hline B & 8 & Photobacterium kishitani (99\%) \\
\hline B & 9 & Photobacterium kishitani/aquimaris (99\%) \\
\hline B & 10 & Vibrio rumoiensis (98\%) \\
\hline $\mathrm{C}$ & 11 & Psychrobacter pulmonis (99\%) \\
\hline $\mathrm{C}$ & 12 & Psychrobacter pulmonis (100\%) \\
\hline $\mathrm{C}$ & 13 & Pseudoalteromonas aliena (99\%) \\
\hline $\mathrm{C}$ & 15 & Vibrio rumoiensis/litoralis (98\%) \\
\hline $\mathrm{D}$ & 16 & Pseudoalteromonas paragorgicolalelyakovi/distincta/nigrifaciens (99\%) \\
\hline D & 17 & Vibrio lentus $(100 \%)$ \\
\hline $\mathrm{D}$ & 18 & Pseudoalteromonas marina (98\%) \\
\hline D & 19 & Pseudoalteromonas translucida (99\%) \\
\hline $\mathrm{D}$ & 20 & Psychrobacter piscatorii/nivimaris (99\%) \\
\hline E & 21 & Photobacterium frigidiphilum (99\%) \\
\hline E & 22 & Photobacterium frigidiphilum (99\%) \\
\hline E & 23 & Photobacterium frigidiphilum (99\%) \\
\hline E & 24 & Photobacterium frigidiphilum (99\%) \\
\hline E & 25 & Photobacterium frigidiphilum (99\%) \\
\hline F & 26 & Pseudoalteromonas paragorgicolalelyakovi/distincta/nigrifaciens (99\%) \\
\hline $\mathrm{F}$ & 27 & Pseudomonas arctica/Alteromonas fuliginea (99\%) \\
\hline $\mathrm{F}$ & 28 & Psychromonas arctica (99\%) \\
\hline $\mathrm{F}$ & 29 & Psychromonas arctica (99\%) \\
\hline $\mathrm{F}$ & 30 & Pseudoalteromonas paragorgicolalelyakoviddistincta/nigrifaciens (99\%) \\
\hline G & 31 & Psychromonas arctica (99\%) \\
\hline G & 32 & Psychromonas arctica (99\%) \\
\hline G & 33 & Pseudoalteromonas marina (98\%) \\
\hline G & 34 & Polaribacter sejongensis/butkevichii (98\%) \\
\hline G & 35 & Psychromonas arctica (99\%) \\
\hline $\mathrm{H}$ & 36 & Pseudoalteromonas paragorgicolalelyakovi/distincta/nigrifaciens (100\%) \\
\hline $\mathrm{H}$ & 37 & Pseudoalteromonas paragorgicola/elyakovi/distincta/nigrifaciens (100\%) \\
\hline $\mathrm{H}$ & 38 & Pseudoalteromonas paragorgicolalelyakovi/distincta/nigrifaciens (100\%) \\
\hline $\mathrm{H}$ & 39 & Pseudoalteromonas paragorgicolalelyakovi/distincta/nigrifaciens (100\%) \\
\hline $\mathrm{H}$ & 40 & Pseudoalteromonas paragorgicolalelyakovi/distincta/nigrifaciens (100\%) \\
\hline I & 41 & Alivibrio logeisalmonicida (100\%) \\
\hline I & 42 & Pseudoalteromonas paragorgicola/elyakovi/distincta/nigrifaciens (100\%) \\
\hline I & 43 & Pseudoalteromonas paragorgicola/elyakovi/distincta/nigrifaciens (100\%) \\
\hline I & 44 & Pseudoalteromonas paragorgicola/elyakovi/distincta/nigrifaciens (100\%) \\
\hline I & 45 & Pseudoalteromonas traslucida (99\%) \\
\hline $\mathrm{L}$ & 46 & Pseudomonas sabulinigri (98\%) \\
\hline $\mathrm{L}$ & 47 & Psychromonas arctica (99\%) \\
\hline $\mathrm{L}$ & 49 & Shewanella vesiculosalivingstonensis (98\%) \\
\hline $\mathrm{L}$ & 50 & Pseudoalteromonas paragorgicolalelyakovi/distincta/nigrifaciens (100\%) \\
\hline M & 51 & Pseudoalteromonas paragorgicola/elyakovi/distincta/nigrifaciens (100\%) \\
\hline M & 52 & Shewanella arctica/frigidimarina $(100 \%)$ \\
\hline M & 53 & Pseudoalteromonas paragorgicola/elyakovi/distincta/nigrifaciens (100\%) \\
\hline M & 54 & Pseudoalteromonas paragorgicolalelyakovi/distincta/nigrifaciens (100\%) \\
\hline M & 55 & Pseudoalteromonas paragorgicola/elyakovi/distincta/nigrifaciens (100\%) \\
\hline $\mathrm{N}$ & 56 & Photobacterium kishitanipiscicola (99\%) \\
\hline $\mathrm{N}$ & 57 & Photobacterium aquimaris (98\%) \\
\hline $\mathrm{N}$ & 58 & Photobacterium kishitanipiscicola (99\%) \\
\hline $\mathrm{N}$ & 59 & Photobacterium kishitanipiscicola (99\%) \\
\hline $\mathrm{N}$ & 60 & Photobacterium kishitani/piscicola (99\%) \\
\hline
\end{tabular}


paragorgicola, elyakovi, distincta and nigrifaciens. Our sequences did not allow the distinction of one of these 4 species due to the high similarity existing among them. Two isolates resulted to be similar to $P$ s. marina, two as $P$ s. translucida and one as Ps. aliena, all often isolated from marine environment (Nam et al., 2007; Ivanova et al., 2002, 2004).

Fourteen colonies (24.1\%) were identified as Photobacterium spp., genus that comprises 19 species, five of those containing luminous strains (Ph. phosphoreum, Ph. kishitani, Ph. angustum, Ph. ganghwense, Ph. leiognathi): all these bacteria are commonly present in marine environments and occur in seawater, surfaces and gut of marine animals, marine sediments and saline lake water, as well as in the organs of fishes (Baumann and Baumann, 1984; Dalgaard, 1995; Urbanczyk et al., 2011). Five of the isolates resulted to be related to $P h$. frigidiphilum, a psychrophilic and weakly halophilic strain, firstly isolated and identified from deep-sea sediments of Edison Seamount (Seo et al., 2005). Seven other isolates showed to be close to Ph. kishitani: for two isolates the species was confirmed with both the alignment tools while for five of them the species indicated in Blast algorithm differed and resulted as $P h$. piscicola, a recent new one (Figge et al., 2014), not yet included in the LeBibi data bank. One strain was related to $P h$. aquimaris and one resulted to be similar with the same score to both the species Ph. kishitani and Ph. aquimaris: according to Yoshizawa et al. (2009), who firstly identified the latter species, these two are recognised to be very closely related from a genetic point of view. All the six isolates recognised as Psychromonas spp. (10.3\% of the whole) resulted to be close to $P$ s. arctica, firstly identified in 2002: these cold-adapted microorganisms could be isolated from permanently but also temporarily cold locations (e.g., oceans, polar regions, high mountains, deep lakes), and are often associated with plants and fresh and cold blooded fishes and crustaceans (Groudieva et al., 2003).

Four isolates clustered with the genus Psychrobacter spp. (6.9\% of the whole): these microorganisms are usually halotolerant and psychrophilic and are linked to several different substrates like fish skin, gills and gut, sea water but also lamb carcasses (Bowman et al., 1997b; Gonzalez et al., 2000; Prieto et al., 1992). Two of these isolates resulted to be related to $P$. pulmonis, the only species not related to marine environment as firstly isolated and identified in 2002 from a pure culture from lung clinical specimen of lambs. Another one resulted to be close to $P$. submarinus, firstly isolated from sea water (Romanenko et al., 2002) and another one to $P$. piscatorii/nivimaris, species firstly isolated from a drain of a fish-processing plant (Yumoto et al., 2010) and from samples of the Southern Ocean environment (Heuchert et al., 2004). As shown by Yumoto et al. (2010), the two species $P$. piscatorii and $P$. nivimaris have a deep genetic relatedness. Three isolates were identified as Vibrio spp. (5.2\%): one resulted to be related to Vibrio lentus, firstly isolated from Mediterranean Oysters (Macian et al., 2001), and the other to Vibrio rumoiensis, firstly isolated from drain pool of a fish product processing plant (Yumoto et al., 2013). The third isolate was close to $V$. rumoiensis/litoralis: these two species are considered strictly related, as observed by Nam et al. (2007). Some species of Vibrio (Vibrio vulnificus and V. parahaemolyticus in particular) are primary causes of human mortality and illness due to gastroenteritis or septicemia through consumption of raw or undercooked seafood or from wound infections (Constantin de Magny et al. 2009). The majority of $V$. vulnificus and $V$. parahaemolyticus illnesses are often related with shellfish consumption; nevertheless, these bacteria can also be found in fish, sediment, plankton and marine water: in our study we did not focus on the presence and isolation of pathogenic bacteria, such as Vibrio spp., thus the colonies identified were isolated from a non-selective medium used for the enumeration of total viable count, and not from a specific medium for the isolation of these bacteria.

Two strains were identified as Shewanella spp.: one resulted to be similar to the species $S$. vesiculosa, firstly isolated from marine sediments collected at Deception Island, and S. livingstonensis, firstly isolated from Antarctic coastal marine environments (Bozal et al., 2002; 2009). The other strain was related to Shewanella arctica/frigidimarina, firstly isolated respectively from Arctic marine sediment in a fjord branch in Norway and from sea ice from Antarctic meromictic lakes (Bowman et al., 1997a; Kim et al., 2012).

Two strains were identified as Pseudomonas spp.: one as Pseudomonas sabulinigri, firstly isolated from black sand collected from Korea (Kim et al., 2009) and one as Pseudomonas arctica/Alteromonas fuliginea.

The remaining two isolates were identified as Alivibrio logei/salmonicida, two psychrophilic species whose substantial similarities were highlighted by multigenic analysis (Ast et al., 2009), and as Polaribacter sejongensis/butkevichii firstly isolated from Antarctic soil and from sea water collected in the Sea of Japan (Kim et al., 2013; Nedashkovskaya et al., 2005).

Keeping into account only unique identifications, total number of bacterial species was 68: the 13 unique species observed are nearly $19 \%$ of total number of species. Nevertheless, considering ambiguous identifications, an algorithm was build up and performed in SAS software (SAS Institute, Cary, NC, USA) by which, the estimates were calculated for 100,000 random possible species compositions of a sample. According with this simulation, the highest value found for number of bacterial species was 53 , while the mean number was 37. Number of total bacterial species colonising lobster meat calculated according only unique identifications should be considered as an over-estimation: as a consequence, values coming from simulation are better estimates of such species richness.

The results of our identifications partially agree with those obtained by Gornik et al. (2011) in Norway lobster (Nephrops norvegicus) tail meat. In fact most of the microbial spoilage population found was composed by the same genera Vibrio spp., Photobacterium spp., Pseudoalteromonas spp., Shewanella spp. and Psychrobacter spp., but the relative frequencies were quite different. In particular, the most prevalent genus in American lobsters was Pseudoalteromonas spp., while only few Vibrio spp. were found, while in Norway lobsters, Vibrio spp. represented more than half of the isolates and only $14.6 \%$ belonged to the

Table 3. Lipolytic and proteolytic abilities of the fifty-eight isolates from American lobsters meat.

\begin{tabular}{lcc} 
& Lipolytic activity (\%) & Proteolytic activity (\%) \\
Total of the colonies identified & $75.5(46 / 58)$ & $69.3(38 / 58)$ \\
Pseudoalteromonas spp. & $100(24 / 24)$ & $100(24 / 24)$ \\
\hline Photobacterium spp. & $50.0(7 / 14)$ & $35.7(5 / 14)$ \\
Psychromonas spp. & $83.3(5 / 6)$ & $16.7(1 / 6)$ \\
\hline Psychrobacter spp. & $50.0(2 / 4)$ & $0(0 / 4)$ \\
Vibrio spp. & $66.7(2 / 3)$ & $33.3(1 / 3)$ \\
\hline Pseudomonas spp. & $100(2 / 2)$ & $50(1 / 2)$ \\
Shewanella spp. & $100(2 / 2)$ & $100(2 / 2)$ \\
\hline Polaribacter spp. & $0(0 / 1)$ & $0(0 / 1)$ \\
Alivibrio spp. & $0(0 / 1)$ & $0(0 / 1)$
\end{tabular}


genus Pseudoalteromonas.

Considering the genera identified, a clear inhomogeneity in the samples distribution was observed with some of them showing a strict prevalence of Pseudoalteromonas spp. (e.g., subjects code A, D, H, I, M) and some others of Photobacterium spp. (B, E, N). As a result, a single subject is not reflecting the microbial population of all the conspecifics and consequently it is quite difficult to predict the development of the spoilage microbiota in this product. In any case, all the identified spoilage microorganisms were common natural marine bacteria, and no important post-harvest contamination by not halophilic bacteria, due to handling or cross contamination, was evidenced. All the genera, apart from Vibrio spp., are microbial spoilers of seafood (Dalgaard, 2000; Gram and Huss, 1996; Gram et al., 1987; Huss, 1995; Shewan, 1977).

All the isolates were screened for their proteolytic and lipolytic ability (Table 3), showing the wide diffusion of metabolically active strains. In particular, all Pseudoalteromonas spp. isolates resulted to possess lipolytic abilities and also proteolytic capabilities. Photobacterium spp., Psychrobacter spp., Vibrio spp. and Psychromonas spp. showed better lipolytic activity than proteolytic. None of the isolates in this study showed the ability to produce $\mathrm{H}_{2} \mathrm{~S}$ : this finding is in agreement with the data obtained from fresh Norway lobsters (Gornik et al., 2011) where all the isolates showed not to possess this capability.

\section{Conclusions}

To our knowledge, no specific studies have been conducted so far about the microbiological quality of American lobsters' meat in terms of spoilage microbial population. The genera isolated from meat samples, mostly characterised by marine Pseudoalteromonas spp. and Photobacterium spp., could be considered rapresentative of the microbiota of not-surviving subjects, but our data could also reflect the microbial environment of live lobsters, transported and stored in similar conditions. The evaluation of not surviving lobsters is of particular concern as they could be an optimal substrate for the growth of spoilage bacteria. Our samples showed very limited microbial loads, suggesting the possibility to commercialise these subjects without particular quality faults for the consumers. The application of good hygienical practices, especially during the production of ready-to-eat lobsters-based products, and a proper ice storage could limit the possible replication of these microorganisms.

\section{References}

Ast J, Urbanczyk H, Dunlap PV, 2009. Multigene analysis reveals previously unrecognized phylogenetic diversity in Aliivibrio. Syst Appl Microbiol 32:379-86.

Barrento S, Marques A, Teixeira B, Vaz-pires P, Nunes ML, 2009. Nutritional quality of the edible tissues of European lobster Homarus gammarus and American lobster Homarus americanus. J Agr Food Chem 57:3645-52.

Baumann P, Baumann L, 1984. Genus II. Photobacterium Beijerink 1889, 401AL. In: Krieg NR, Holt JG, eds. Bergey's manual of systematic bacteriology. Williams and Wilkins, Baltimore, MD, USA, pp 539-45.

Bernardi C, Baggiani L, Tirloni E, Stella S, Colombo F, Moretti VM, Cattaneo P, 2015. Hemolymph parameters as physiological biomarkers in American lobster Homarus americanus for monitoring the effects of two commercial maintenance methods. Fish Res 161:280-4.

Bowman JP, McCammon SA, Nichols DS, Skerratt JH, Rea SM, Nichols PD, McMeekin TA, 1997a. Shewanella gelidimarina sp. nov. and Shewanella frigidimarina sp. nov., novel Antarctic species with the ability to produce eicosapentaenoic acid 20:5 3 and grow anaerobically by dissimilatory FeIII reduction. Int J Syst Bacteriol 47:1040-7.

Bowman JP, Nichols DS, McMeekin TA, 1997b. Psychrobacter glacincola sp. nov., a halotolerant, psychrophilic bacterium isolated from Antarctic Sea ice. Syst Appl Microbiol 20:209-15.

Bozal N, Montes MJ, Galbis DM, Manresa A, Mercade E, 2009. Shewanella vesiculosa sp. nov., a psychrotolerant bacterium isolated from an Antarctic coastal area. Int $\mathrm{J}$ Syst Evol Micr 59:336-40.

Bozal N, Montes MJ, Tudela E, Jimenez F, Guines J, 2002. Shewanella frigidimarina and Shewanella livingstonensis sp. nov. isolated from Antarctic coastal areas. Int J Syst Evol Micr 52:195-205.

Chao A, Colwell RK, Lin C-W, Gotelli NJ, 2009. Sufficient sampling for asymptotic minimum species richness estimators. Ecology 90:1125-33.

Constantin de Magny G, Long W, Brown C, Hood R, Huq A, Murtugudde R, Colwell R, 2009. Predicting the distribution of Vibrio spp. in the Chesapeake Bay: a Vibrio cholerae case study. EcoHealth 6:378-89.

Dalgaard P, 1995. Qualitative and quantitative characterization of spoilage bacteria from packed fish. Int J Food Microbiol 26:31933.

Dalgaard P, 2000. Freshness, quality and safety in seafoods. Flair-flow Europe technical manual F-FE 380A / 00. Teagasc-The National Food Centre, Dublin, Ireland.

Espe M, Kiessling A, Lunestad B-T, Torrissen OJ, Bencze AM, Lebensm R, 2004. Quality of cold smoked salmon collected in one French hypermarket during a period of 1 year. Food Sci Technol 37:627-38.

FA0, 2006. The state of fisheries and aquaculture. Fisheries and Aquaculture Department, Food and Agriculture Organization, Rome, Italy. Available from: ftp://ftp.fao.org/docrep/fao/009/a0699e/a06 99e.pdf

Figge MJ, Cleenwerck I, van Uijen A, De Vos P, Huys G, Robertson L, 2014. Photobacterium piscicola sp. nov., isolated from marine fish and spoiled packed cod. Syst Appl Microbiol 37:329-35.

FDA, 2013. Revised guidelines for the assessment of microbiological quality of processed food. Food and Drug Administration, Silver Spring, MD, USA.

Fotedar S, Evans L, 2011. Health management during handling and live transport of crustaceans: a review. J Invertebr Pathol 106:143-52.

Frazier WC, 1926. A method for the detection of changes in gelatin due to bacteria. $\mathrm{J}$ Infect Dis 39:302-9.

Gonzalez CJ, Santos JA, García-López M-L, Otero A, 2000. Psychrobacters and related bacteria in freshwater fish. J Food Protect 3:299-418.

Gornik SG, Albalab A, Macpherson H, Birkbeck H, Neil DM, 2011. The effect of temperature on the bacterial load and microbial composition in Norway lobster Nephrops norvegicus tail meat during storage. J Appl Microbiol 111:582-92.

Gram L, Huss HH, 1996. Microbiological spoilage of fish and fish products. Int $\mathrm{J}$ Food Microbiol 33:121-37.

Gram L, Trolle G, Huss HH, 1987. Detection of specific spoilage bacteria from fish stored at low $0^{\circ} \mathrm{C}$ and high $20^{\circ} \mathrm{C}$ temperatures. Int J Food Microbiol 4:65-72.

Gregersen T, 1978. Rapid method for distinction of Gram-negative and Gram-positive bacteria. Eur J Appl Microbiol Biotech 5:123-7.

Groudieva T, Grote R, Antranikian G, 2003. Psychromonas arctica sp. nov., a novel psychrotolerant, biofilm-forming bacterium isolated from Spitzbergen. Int J Syst Evol Micr 53:539-45.

Heuchert A, Glöckner F0, Amann R, Fischer U, 
2004. Psychrobacter nivimaris sp. nov., a heterotrophic bacterium attached to organic particles isolated from the South Atlantic Antarctica. Syst Appl Microbiol 27:399-406.

Hugh R, Leifson E, 1953. The taxonomic significance of fermentative versus oxidative metabolism of carbohydrates by various gram-negative rods. J Bacteriol 66:24-6.

Huss HH, 1995. Quality and quality changes in fresh fish. Food and Agriculture Organization, Rome, Italy.

ICMSF, 1998. Microorganisms in Foods 6: microbial ecology of food commodities. International Commission on Microbiological Specifications for Foods, New York, NY, USA.

ISO, 2004. Microbiology of food and animal feeding stuffs. Horizontal methods for the detection and enumeration of Enterobacteriaceae. Part 2: colony-count method. ISO Norm 21528-2:2004. International Organization for Standardization, Geneva, Switzerland.

Ivanova EP, Bakunina Y, Nedashkovskaya OI, Gorshkova NM, Alexeeva YV, 2003. Ecophysiological variabilities in ectohydrolytic enzyme activities of some Pseudoalteromonas species, P. citrea, P. issachenkonii, and P. nigrifaciens. Curr Microbiol 46:6-10.

Ivanova EP, Gorshkova NM, Zhukova AM, Zelepuga EA, Prokof'eva VV, Nicolau DV, Christen R, 2004. Characterization of Pseudoalteromonas distincta-like seawater isolates and description of Pseudoalteromonas aliena sp. nov.. Int $\mathrm{J}$ Syst Evol Micr 54:1431-7.

Ivanova EP, Sawabe T, Alexeeva YV, Lysenko AM, Gorshkova NM, Hayashi K, Zukova NV, 2002. Pseudoalteromonas issachenkonii sp. nov., a bacterium that degrades the thallus of the brown alga Fucus evanescens. Int J Syst Evol Micr 52:229-34.

Kim CB, Oh HW, Park D-S, Hong SG, Lee HK, Bae KS, 2013. Polaribacter sejongensis sp. nov., isolated from Antarctic soil, and emended descriptions of the genus Polaribacter, Polaribacter butkevichii and Polaribacter irgensii. Int J Syst Evol Micr 63:4000-5.

Kim K-H, Roh HK, Chang HK, Nam Y-D, Yoon J-H, Jeon CO, Oh H-M, Bae JW, 2009. Pseudomonas sabulinigri sp. nov., isolated from black beach sand. Int J Syst Evol Micr
59:38-41.

Kim S-J, Park S-J, Oh Y-S, Lee S-A, Shin K-S, Roh D-H, Rhee S-K, 2012. Shewanella arctica sp. nov., an iron-reducing bacterium isolated from Arctic marine sediment. Int $\mathrm{J}$ Syst Evol Micr 62:1128-33.

King EO, Ward MK, Raney DE, 1954. Two simple media for the demonstration of pyocyanin and fluorescin. J Lab Clin Med 44:301-7.

Kovacs N, 1956. Identification of Pseudomonas pyocyanea by the oxidase reaction. Nature 178:703.

Liston J, 1980. Microbiology in fishery science. In: Connell JJ, ed. Advances in fishery science and technology. Fishing News Books, Farnham, UK, pp 138-157.

Macian MC, Ludwig W, Aznar R, Grimont PAD, Schleifer KH, Garay E, Pujalte MJ, 2001. Vibrio lentus sp. nov., isolated from Mediterranean oysters. Int J Syst Evol Micr 51:1449-56.

Makemson JC, Fulayfil N, Basson P, 1992. Association of luminous bacteria with artificial and natural surfaces in Arabian Gulf seawater. Appl Environ Microb 58:2341-3.

Nam Y-D, Chang H-W, Park JR, Kwon H-J, Quan X-Z, Park Y-H, Kim B-C, Bae JW, 2007. Vibrio litoralis sp. nov., isolated from a Yellow Sea tidal flat in Korea. Int J Syst Evol Micr 57:562-5.

Nam Y-D, Chang H-W, Park JR, Kwon H-J, Quan Z-X, Park YH, Lee J-S, Yoon J-H, Bae J-W, 2007. Pseudoalteromonas marina sp. nov., a marine bacterium isolated from tidal flats of the Yellow Sea, and reclassification of Pseudoalteromonas sagamiensis as Algicola sagamiensis comb. nov.. Int $\mathbf{J}$ Syst Evol Micr 57:12-8.

Nedashkovskaya OI, Kim SB, Lysenko AM, Kalinovskaya NI, Mikhailov VV, Kim IS, Bae KS, 2005. Polaribacter butkevichii sp. nov., a novel marine mesophilic bacterium of the family Flavobacteriaceae. Curr Microbiol 51:408-12.

Olafsdottir G, Chanie E, Westad F, Luten J, Kristbergsson K, 2005. Prediction of microbial and sensory quality of cold smoked atlantic salmon Salmo salar by electronic nose. J Food Sci 70:563-74.

Prieto M, García-Armesto MR, García-López ML, Otero A, Moreno B, 1992. Numerical taxonomy of gram-negative, nonmotile, nonfermentative bacteria isolated during chilled storage of lamb carcasses. Appl
Environ Microb 58:2245-9.

Romanenko LA, Schumann P, Rohde M, Lysenko AM, Mikhailov VV, Stackebrandt E, 2002. Psychrobacter submarinus sp. nov. and Psychrobacter marincola sp. nov., psychrophilic halophiles from marine environments. Int J Syst Evol Micr 52:1291-7.

Rudi K, Skulberg OM, Larsen F, Jacoksen KS, 1997. Strain classification of oxyphotobacteria in clone cultures on the basis of $16 \mathrm{~S}$ rRNA sequences from variable regions V6, V7 and V8. Appl Environ Microb 63:2593-9.

Seo HJ, Bae SS, Lee J-H, Kim S-J, 2005. Photobacterium frigidiphilum sp. nov., a psychrophilic, lipolytic bacterium isolated from deep-sea sediments of Edison Seamount. Int J Syst Evol Micr 55:1661-6.

Shewan JM, 1977. The bacteriology of fresh and spoiling fish and the biochemical changes induced by bacterial action. Torry Research Station, Torry, UK.

Sierra G, 1957. A simple method for the detection of lipolytic activity of micro-organisms and some observations on the influence of the contact between cells and fatty substrates. A Van Leeuw J Microb 23:15-22.

Swartzentruber A, Schwab AH, Duran AP, Wentz BA, Read Jr. RB, 1980. Microbiological quality of frozen shrimp and lobster tail in the retail market. Appl Environ Microb 40:765-9.

Urbanczyk H, Ast JC, Dunlap PV, 2011. Phylogeny, genomics, and symbiosis of Photobacterium. FEMS Microbiol Rev 35:324-42.

Yoshizawa S, Wada M, Kita-Tsukamoto K, Yokota A, Kogure K, 2009. Photobacterium aquimaris sp. nov., a luminous marine bacterium isolated from seawater. Int $\mathrm{J}$ Syst Evol Micr 59:1438-42.

Yumoto I, Hirota K, Kimoto H, Nodasaka Y, Matsuyama H, Yoshimune K, 2010. Psychrobacter piscatorii sp. nov., a psychrotolerant bacterium exhibiting high catalase activity isolated from an oxidative environment. Int $\mathrm{J}$ Syst Evol Microbiol 60:205-8.

Yumoto I, Ichihashi D, Iwata H, Istokovics A, Ichise N, Matsuyama H, Okuyama H, Kawasaki K, 2013. Purification and characterization of a catalase from the facultatively psychrophilic bacterium Vibrio rumoiensis S-1T exhibiting high catalase activity. J Bacteriol 182:1903-9. 